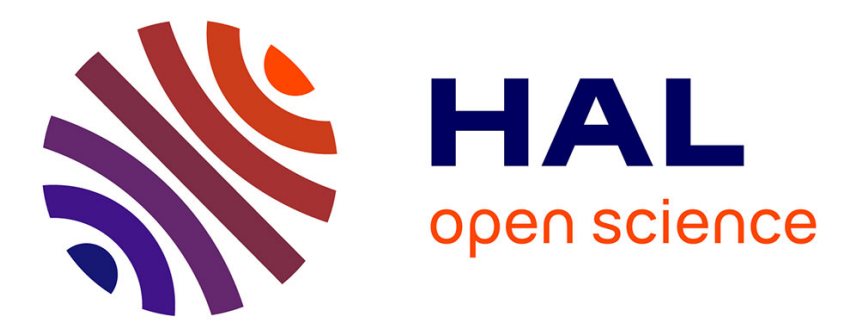

\title{
Heterogeneity in exchange rate expectations: evidence on the chartist-fundamentalist approach
}

\author{
Lukas Menkhoff, Rafael R. Rebitzky, Michael Schröder
}

\section{To cite this version:}

Lukas Menkhoff, Rafael R. Rebitzky, Michael Schröder. Heterogeneity in exchange rate expectations: evidence on the chartist-fundamentalist approach. Journal of Economic Behavior and Organization, 2009, 70 (1-2), pp.241. 10.1016/j.jebo.2009.01.007 . hal-00662383

\section{HAL Id: hal-00662383 https://hal.science/hal-00662383}

Submitted on 24 Jan 2012

HAL is a multi-disciplinary open access archive for the deposit and dissemination of scientific research documents, whether they are published or not. The documents may come from teaching and research institutions in France or abroad, or from public or private research centers.
L'archive ouverte pluridisciplinaire HAL, est destinée au dépôt et à la diffusion de documents scientifiques de niveau recherche, publiés ou non, émanant des établissements d'enseignement et de recherche français ou étrangers, des laboratoires publics ou privés. 


\section{Accepted Manuscript}

Title: Heterogeneity in exchange rate expectations: evidence on the chartist-fundamentalist approach

Authors: Lukas Menkhoff, Rafael R. Rebitzky, Michael Schröder

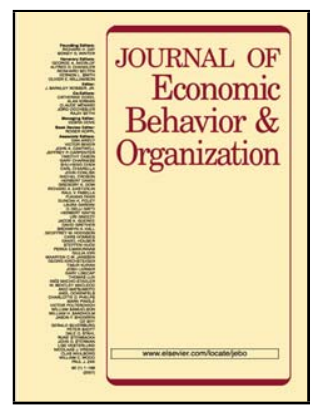

PII:

S0167-2681(09)00026-2

DOI: doi:10.1016/j.jebo.2009.01.007

Reference: JEBO 2306

To appear in: Journal of Economic Behavior \& Organization

Received date: $\quad 23-4-2007$

Revised date: $\quad 17-1-2009$

Accepted date: $\quad 19-1-2009$

Please cite this article as: Menkhoff, L., Rebitzky, R.R., Schröder, M., Heterogeneity in exchange rate expectations: evidence on the chartist-fundamentalist approach, Journal of Economic Behavior and Organization (2008), doi:10.1016/j.jebo.2009.01.007

This is a PDF file of an unedited manuscript that has been accepted for publication. As a service to our customers we are providing this early version of the manuscript. The manuscript will undergo copyediting, typesetting, and review of the resulting proof before it is published in its final form. Please note that during the production process errors may be discovered which could affect the content, and all legal disclaimers that apply to the journal pertain. 


\title{
Heterogeneity in exchange rate expectations: evidence on the chartist-fundamentalist approach
}

\author{
Lukas Menkhoff, Leibniz Universität Hannover, Germany, \\ Rafael R. Rebitzky, Leibniz Universität Hannover, Germany, and \\ Michael Schröder, Centre for European Economic Research, Mannheim, Germany
}

\begin{abstract}
This paper examines heterogeneity in exchange rate expectations. Whereas agents' heterogeneity is key in modern exchange rate models, evidence on determinants of heterogeneity is weak thus far. Our sample, covering expectations from about 300 forecasters over 15 years, shows remarkable time variation in dispersion. Determinants of dispersion are consistent with the chartist-fundamentalist approach: misalignments of the exchange rate and exchange rate changes explain heterogeneity. The risk premium influences heterogeneity as well, but possible impacts from macroeconomic variables and exchange rate's volatility are dominated by the other determinants.
\end{abstract}

JEL classification: F31, G14

Keywords: $\quad$ exchange rate, heterogeneity, dispersion, chartists, fundamentalists

January 16, 2009

We thank two anonymous referees for their very useful comments. Financial support by the Deutsche Forschungsgemeinschaft is gratefully acknowledged.

Lukas Menkhoff and Rafael R. Rebitzky, Leibniz Universität Hannover, Department of Economics, Königsworther Platz 1, D-30167 Hanover, Germany; email: menkhoff@gif.unihannover.de, rebitzky@gif.uni-hannover.de Michael Schröder, Centre for European Economic Research, L7 1, D-68161 Mannheim, Germany, email: schroeder@zew.de 


\section{Heterogeneity in exchange rate expectations: evidence on the chartist-fundamentalist approach}

\section{Introduction}

It has become apparent that we cannot understand exchange rate behavior by relying on models with representative agents. All forms of these simplifying asset approach models have failed empirically (see Sarno and Taylor, 2002). ${ }^{1}$ However, not only do they disappoint regarding their purpose (i.e. to explain the dynamics in exchange rates), but they seem to be conceptually misleading as well. There is now abundant evidence that market participants have quite heterogeneous expectations on future exchange rates. ${ }^{2}$ This may explain why we observe a tremendous trading volume on foreign exchange markets that is larger than the volume on the world's leading stock exchanges, not to mention trade in goods and services. Obviously, investor heterogeneity is key in understanding exchange rate dynamics, and thus it is crucial to implement some form of heterogeneity in such models (see e.g. Lux, 1998, Westerhoff, 2003, De Grauwe and Grimaldi, 2006). ${ }^{3}$ However, empirical studies on expectation heterogeneity have mainly studied cross-sectional differences, whereas this paper is the first (according to our knowledge) to examine the causes of heterogeneity in exchange rate expectations in the time-series dimension thoroughly.

The goal of this research is to examine whether determinants of heterogeneity in exchange rate expectations, as indicated by the literature, hold in a time-series examination. In doing so, we rely on a monthly dataset covering expectations of about 300 professionals on three major exchange rates over 15 years. This data serves to measure dispersion of individual expectations as our proxy of expectation heterogeneity. Due to the very persistent nature of some of the time-series, we apply the vector error-correction (VEC) framework. Our universe of potential determinants is derived from three strands of literature (which we introduce in more detail below): first, and at the core of interest, we regard determinants introduced in models of heterogeneous agents (chartists and fundamentalists) that have been widely used (see e.g. Frankel and Froot, 1990a, Brock and Hommes, 1998, Lux, 1998, De Grauwe and Grimaldi, 2006). Second, we consider the argument that noise traders create risk and thus

\footnotetext{
${ }^{1}$ This literature begins with Meese and Rogoff (1983); their results have been frequently confirmed ever since (see e.g. Frankel and Rose 1995, Cheung et al. 2005).

${ }^{2}$ See, for example, Frankel and Froot (1987), Ito (1990), MacDonald and Marsh (1996), Elliott and Ito (1999).
} 
heterogeneity (e.g. Flood and Rose, 1996, Mark and Wu, 1998), and, third, we take up impulses from information heterogeneity about the macroeconomic fundamentals that may also explain heterogeneity in exchange rate expectations (e.g. Sims, 2003, Bacchetta and van Wincoop, 2006a). ${ }^{4}$ As the first strand, the modeling approach of chartists and fundamentalists, has dominated exchange rate research with respect to heterogeneous agents, the examination of the two other strands may serve as a means of verifying the robustness of the chartistfundamentalist approach (C\&F approach). ${ }^{5}$

We find that the universe of potential determinants of heterogeneity in exchange rate expectations boils down to three main variables that provide support to models of chartists and fundamentalists: heterogeneity is positively related to, first, uncertainty among fundamentalists, and second, a shift from dominating fundamentalists to the minor group of chartists. Third, these measures even hold if a risk premium is introduced, indicating uncertainty, which increases heterogeneity as well. Moreover, the consideration of macroeconomic variables measured in absolute, in change or alternatively in volatility form, does not contribute significantly to the explanation of expectation heterogeneity. Finally, risk captured by lagged exchange rate volatility explains heterogeneity only if we do not control for the three determinants introduced above. To conclude, the $\mathrm{C} \& \mathrm{~F}$ approach proves to be useful in explaining dynamics of heterogeneity in exchange rate expectations.

The remainder is structured as follows. Section 2 introduces into the related literature, and Section 3 describes the data we use in our analysis. Ancillary results revealing the existence of expectation heterogeneity are presented in Section 4. The following Section 5 contains the main results concerning the determinants of heterogeneity, and Section 6 concludes.

\section{Literature}

Before giving more detailed results, we introduce the literature that motivates our analysis. The C\&F approach is currently a common way of thinking about expectation heterogeneity in foreign exchange markets. One of the first observation of its potential relevance was the documentation that foreign exchange professionals rely heavily (and

\footnotetext{
${ }^{3}$ See also Chen et al., 2001, Manzan and Westerhoff, 2005, Alfarano and Lux, 2007, and Alfarano et al., 2008.

${ }^{4}$ Referring to Mankiw and Reis' (2002) "sticky information model”, Mankiw et al. (2003) test its implications on inflation expectations amongst others, arising from related macroeconomic variables.

5 The term "chartist-fundamentalist approach" is often used in the literature, among others by Lux (1998), Westerhoff (2003), Manzan and Westerhoff (2005 and 2007) and Alfarano et al. (2008).
} 
possibly also successfully) on technical analysis (see Goodman, 1979). This finding has been expanded into a set of stylized facts. Its main insight related to our research implies that technical analysis is, indeed, of high importance among foreign exchange professionals such as dealers and fund managers, a finding which has held from the 1970s to the present day (see Menkhoff and Taylor, 2007). The idea of switching between these kinds of analyses is based on the fact that technical and fundamental analyses coexist and are typically used by the same persons. Frankel and Froot paved the way with a series of papers aimed in this direction during the mid-1980s; the most complete account of their thinking is documented in Frankel and Froot (1990a). They derive fundamentalists' and chartists' weight from a process in which decision makers learn the right model from their past performance. Whereas fundamentalists anticipate that exchange rates move towards their long-run equilibria, modeled via balanced current accounts, chartists take positions in line with recent exchange rate changes (i.e. they extrapolate exchange rate trends).

Frankel and Froot's (1990a and 1990b) contribution comprises much of the current C\&F approach's intuition; their design is specific, however, and aims at explaining the dollar in the 1980s. Further studies have extended this line of research (e.g. Day and Huang, 1990). Brock and Hommes (1998) simulate the dynamics of a stock market also by relying on heterogeneous agents who choose between different trading strategies due to their prior returns. In fact, the authors generate complex endogenous price dynamics that match stylized facts of financial time series. Since then, several papers have contributed towards refining and extending this line of research; however, the basic intuition remained unchanged. ${ }^{6}$ Due to this fact, we adhere to an indicative example of the $\mathrm{C} \& \mathrm{~F}$ approach, in this case De Grauwe and Grimaldi's model (2006).

De Grauwe and Grimaldi (2006) assume, in line with Frankel and Froot (1990a) and others, that market participants choose between a fundamentalist and a chartist trading strategy. ${ }^{7}$ Fundamentalists are geared to the fundamental exchange rate, stemming from, for example, the purchasing power parity concept (ppp), whereas chartists extrapolate the current trend in the exchange rate. ${ }^{8}$ The fundamental rule predicts higher expected returns and lower risks the farther exchange rates are from equilibria. This implies that expectation

\footnotetext{
${ }^{6}$ Latest contributions include Wieland and Westerhoff (2005), Manzan and Westerhoff (2005 and 2007), Alfarano and Lux (2007), Alfarano et al. (2008), Boswijk et al. (2007), and Chiarella et al. (2007).

${ }^{7}$ In the following, we use the terms chartist and technical trading synonymously.

${ }^{8}$ In fact, De Grauwe and Grimaldi do not base their exchange rate on one single fundamental concept; however, their model presumes that corresponding fundamentals follow a random walk.
} 
heterogeneity decreases in situations that are characterized by increasing exchange rate misalignment. On the other hand, the chartists' impact has proved to be less clear-cut. Obviously, their market share increases, the stronger the trend in the exchange rate becomes. Nevertheless, whether heterogeneity actually decreases or increases depends on the general composition of the market. In our sample, participants rank themselves mainly as fundamentalist and only about $30 \%$ claimed to be chartist (see ZEW, 2004). ${ }^{9}$ Thus, subsequent switches from fundamentalism to chartism will increase expectation heterogeneity. ${ }^{10}$

As a second strand of literature we consider noise trading models, such as Jeanne and Rose (2002). They derive a positive relation between heterogeneity and the exchange risk premium (see Froot and Frankel, 1989) by analyzing the impact of noise trading on exchange rates (although they focus primarily on the current exchange rate regime). Their model shows that the appearance of more unsophisticated traders drives noise trading up and subsequently affects expectation heterogeneity, which in turn causes distortions of uncovered interest parity. In this manner, noise traders drive a wedge between the expected exchange rate and the forward rate, thus creating heterogeneous expectations and risk (see also Flood and Rose, 1996, Mark and Wu, 1998).

Finally, a third strand of literature is provided by studies linking uncertainty about fundamentals to expectation heterogeneity. Bacchetta and van Wincoop (2006a) implement information heterogeneity in a standard monetary model. Assuming the existence of dispersed information without any investor holding superior information, investors have to find out about fundamental information from unobserved trades. As time goes by, agents learn fundamentals, and thus (rational) confusion gradually declines, which incorporates the intermediate situation of information based heterogeneity of expectations. In a different approach, Bacchetta and van Wincoop (2006b) apply the concept of rational inattention to foreign exchange (see also Sims, 2003, and more recently Reis, 2007). It is argued that potential gains from learning the complete information set are small, so agents are not fully

\footnotetext{
${ }^{9}$ The prevalence of fundamentalists in our sample is not surprising, given that the experience from various surveys shows that fund managers and analysts (who dominate our sample) prefer fundamental analysis (and longer time horizons), while short-term orientated investors such as foreign exchange dealers rely more on chart analysis. Summing up, institutional background and investor horizon matter and are in principle related to each other (see Menkhoff and Taylor, 2007).

${ }^{10}$ This is of course a simplification of reality as we know that almost all market participants use fundamental as well as technical analysis simultaneously to some degree. However, it is important to emphasize that the survey participants of our analysis tend in principle towards fundamentalism.
} 
informed, hold different sets of information, and make infrequent portfolio decisions. ${ }^{11}$ Accordingly, heterogeneity should rise in periods of higher news frequency, which would in turn increase the differences between agents' information sets. Such periods may be indicated by higher volatility of fundamentals or, alternatively, by higher exchange rate volatility. ${ }^{12}$

Our relatively long and broad dataset allows us to examine the importance of the above discussed strands of literature in professional expectation data. In actual fact, we find conforming evidence with inherent implications of the C\&F approach: heterogeneity in exchange rate expectations increases with decreasing deviation of the actual exchange rate from purchasing power parity (ppp), indicating declining consensus among fundamentalists. This corresponds well with Kilian and Taylor's (2003) study, which shows that when exchange rates deviate from ppp-values substantially, subsequent adjustments towards their equilibriums are significantly stronger. Moreover, rapid changes in the exchange rate, indicating a shift towards chartism, increase expectation heterogeneity that once again matches with the C\&F approach. In addition, another significant determinant shows up, as presumed by the second strand of literature: a rising exchange risk premium boosts expectation heterogeneity. Further variables as deduced by the third strand, such as volatility in exchange rate fundamentals or in exchange rates, do not provide additional insights. This pattern holds exactly for US-dollar as well as GB-pound versus euro and largely for JP-yen versus euro.

\section{Data}

Our analysis is built on two sorts of data: first, we use a dataset comprising 15 years of individual exchange rate expectations in order to calculate heterogeneity, and, second, we use a large dataset of standard fundamental determinants of exchange rates.

The core variable of our analysis is dispersion, which represents heterogeneity in exchange rate expectations and is defined as the standard deviation of individual exchange rate expectations. In generating dispersion, we rely on the individual expectations from the well-established financial market survey of the Centre for European Economic Research (ZEW) in Mannheim, Germany. The survey provides information on a monthly census of

\footnotetext{
${ }^{11}$ Mankiw et al. (2003) test Mankiw and Reis' "sticky information model" (2002). In particular, they do so by analyzing heterogeneity in inflation expectations. Amongst other determinants, changes and volatility in inflation seem to be the most important.

${ }^{12}$ Frankel and Froot (1990b) find a correlation between exchange rate volatility and dispersion, which they attribute to model heterogeneity (such as the C\&F approach) rather than to heterogeneity in information.
} 
financial market professionals, questioning their 6-months forecasts of various financial and macroeconomic variables. Our sample contains expectations for the US-dollar/euro, GBpound/euro and JP-yen/euro (until end of 1998 /D-mark respectively), from December 1991 until August 2006, which sums up each with 177 observations. Compared to other financial market surveys, the ZEW's survey structure is conventional and similar to Consensus Forecasts (London). Nevertheless, it is worth mentioning that there has been wide participation with about 300 responses on average. Moreover, the design of the survey is of a qualitative nature, in that participants are only required to judge whether the corresponding variable goes up, down or stays unchanged. Due to the fact that our analyses require quantitative forecasts, we have to transform the data by means of a quantification technique. We do so by using Carlson and Parkin's method (1975), which in turn enables us to run appropriate analyses. ${ }^{13}$

The expectation data is introduced in Table 1, which contains descriptive statistics of the aggregated exchange rate expectations. Two figures present the core variable in our analyses (i.e. heterogeneity in exchange rate expectations). For each of the three exchange rates, Figure 1 shows the histogram of dispersion, whereas Figure 2 presents its time-series next to the corresponding exchange rate. Overall, one can see remarkable variation in heterogeneity.

Since the main purpose of our work lies in discovering the determinants of heterogeneity, we need further data. To begin with, we use daily exchange rate data of the US-dollar/euro, GB-pound/euro and JP-yen/euro (-/D-mark respectively) from the Deutsche Bundesbank in order to calculate, amongst others, exchange rate changes and respective volatilities. Moreover, we consider core fundamentals that are used in standard exchange rate models. Taking the monetary model as the reference model, these variables are the following: differences of changes in money and income as well as of interest rates between the euro zone (Germany until December 1998 respectively) and the United States, Great Britain and Japan, respectively. In detail, we use a broader definition of money, M3, and a narrower one, M2. In

${ }^{13}$ Using the method of Carlson and Parkin (1975) to derive aggregate point expectations from directional forecast requires two assumptions. First, each individual forecast is based upon a subjective probability distribution concerning the outcome of this forecast (applying the logistic distribution does not qualitatively change the results). Second, the corresponding means of the individual probability distributions follow a normal distribution that can be justified via the Central-Limit Theorem. Furthermore, we choose a symmetric scaling of three percent, which displays a threshold. Hence, forecasters perceive noticeable changes in the exchange rate, if the latter proves to be three percent or more; this threshold is based upon a particular survey among participants of the ZEW Financial Market Survey. Nevertheless, choosing other thresholds (around three percent) does not reveal qualitatively different results. 
order to proxy income growth on a monthly basis, we rely on industrial production; additionally, quarterly GDP is interpolated to generate a monthly frequency. With respect to interest rates, we use 6-month Libor rates. Furthermore, considering Frankel's (1979) real interest differential model we also incorporate 10-year government bond yields. Finally, and somewhat more pragmatically, we use further variables beyond our reference model. First, inflation is often seen to be a better proxy to capture price trends than money aggregates. Second, the trade balance is often assessed as a further exchange rate determinant (see e.g. Obstfeld and Rogoff, 1995) and, third, capital flows reach beyond money market instruments and bonds, which is why we consider stock index returns as well (see Hau and Rey, 2006). ${ }^{14}$ In the following section we examine which of the above introduced variables, as suggested by the three strands of literature, are related to heterogeneity in exchange rate expectations.

\section{Determinants of expectation heterogeneity}

To get a first idea about the relevant explanatory variables in order to explain heterogeneity in exchange rate expectations, we conduct basic regression analyses. More specifically, we identify three variables of interest that we will pick up again in Section 5. Before we discuss our results, we define the variables that have to be constructed from raw data.

The following variables are deduced from the first strand of literature, underlying the C\&F approach. Frankel and Froot (1990a) explicitly draw on a relation between the expectation formation, the related time horizon and the preferred kind of information. They characterize fundamentalists as forming regressive expectations and being subject to a longer time horizon whereas chartists form extrapolative expectations and are shorter term oriented. Accordingly, considering fundamentalists' equilibrium expectations, we rely on the concept of ppp, which is well-known and popular among professionals as a tool to generate exchange rate equilibrium values (see Westerhoff and Reitz, 2003, Manzan and Westerhoff, 2007). It follows that the absolute difference between the current exchange rate and its ppp-value determines fundamentalists' exchange rate expectations. ${ }^{15}$ Regarding chartists' stance, we simply take the most recent 1 -month change of the exchange rate, again in absolute terms. We

\footnotetext{
${ }^{14}$ 6-month Libor rates and stock indices are taken from EcoWin. M2, M3, industrial productions, GDP, CPI inflation and trade balances stem from IMF's International Financial Statistics. German government bond yields are taken from the Deutsche Bundesbank and US, British, and Japanese yields from the Federal Reserve, the Bank of England and the Bank of Japan, respectively.

${ }^{15}$ The ppp-values are based upon long-run validity of the relative ppp-concept. Respective nominal values are derived from the average real exchange rate by using actual Consumer Price Indices.
} 
feel quite confident that these two variables (a regressive variable based upon ppp and a 1month extrapolative term) adequately capture the behavior of chartists and fundamentalists according to the C\&F-approach.

With respect to the second strand of the literature, we apply the standard definition of the risk premium as the difference between the exchange rate expectation and the accordant forward rate (see e.g. Froot and Frankel, 1989, Bams et al. 2004).

This brings us to the third strand of literature, hypothesizing that further fundamentals determine heterogeneity. We examine the influence of those variables, which have been introduced in Section 3, in three ways: first, we take them in algebraic signed form in order to allow for potential asymmetries. ${ }^{16}$ Second, we consider fundamentals in their absolute form, which somewhat reduces complexity since it does not allow for the above effects. Third, we calculate their volatilities by relying on the 1-month standard deviation in order to capture potential second-moment-elements in dispersion. A full list of the considered variables is given in Appendix 1.

As a first analysis, we run univariate OLS-regressions, where we regress each of the above variables separately on expectation heterogeneity. To cut a long story short, there are only few results worth mentioning. In particular, no fundamental shows a significant relation with heterogeneity in exchange rate expectations, independent of its measured form. This is somewhat surprising, when compared to literature on inflation expectations (see Mankiw et al., 2003), but possibly less so when we remember that hardly any stable relation exists between exchange rate fundamentals and exchange rates except for the long run (e.g. MacDonald, 1999, Sarno and Taylor, 2002).

The few relations we find are presented in Table 2. The table shows the R-squares of regressions of the regressive term, the extrapolation variable and the risk variable, as well as exchange rate volatility on heterogeneity. Obviously, it is better to measure the series in absolute terms to explain dispersion instead of considering asymmetric effects in expectation heterogeneity with respect to the determinants' signs. However, with regard to conducting multivariate regressions, we see in Table 3 that the correlation of volatility with dispersion is completely absorbed by the other variables for any exchange rate. Volatility becomes insignificant whereas the other variables remain significant in the multivariate setting. ${ }^{17}$

\footnotetext{
${ }^{16}$ See Elliott et al. (2008) studying heterogeneity in output forecasts, and further studies of expectation heterogeneity in inflation, Mankiw et al. (2003) and Capistrán and Timmermann (2006).

${ }^{17}$ Excluding volatility from the regressions, the $\mathrm{R}^{2}$ s remain nearly unchanged while the other parameters do not change in a meaningful way. Since Durbin Watson statistics indicate strong autocorrelation, we implement dispersion with lag one in the multivariate regressions.
} 
Overall, we find that the bulk of potentially relevant variables boils down to three: the two variables derived from the $\mathrm{C} \& \mathrm{~F}$ approach and the risk premium. Moreover, since we do not reveal any sign of asymmetric effects underlying dispersion, we define these variables in absolute terms. In the next section, we apply a VEC approach in order to account for the persistent behavior of some of the variables and thus to discriminate between temporary and permanent effects.

\section{Expectation heterogeneity in a VEC approach}

The VEC model reveals permanent and temporary effects with some differences between the three exchange rates under consideration. However, we emphasize that all three empirical models have a similar structure, indicating the existence of common determinants of heterogeneity in exchange rate expectations.

There are two justifications for choosing the VEC approach. First, we cannot rule out a priori, that some explanatory variables of the multivariate regressions presented in Section 4 are in fact endogenous; to quote an example, dispersion could have an impact on the risk premium. Second, given that some of the time-series are very persistent, an error-correction approach appears justified in order to pick up the common stochastic trends that could be present amongst the variables. ${ }^{18}$

Our baseline model contains the four variables identified in Section 4: dispersion as our measure of expectation heterogeneity, the ppp-deviation term, the 1-month extrapolation variable and the risk premium. In addition to this, we test each exchange rate model separately for constants and dummy variables. ${ }^{19}$ Thus, our baseline model shows up as follows:

$$
\begin{gathered}
\Delta \mathbf{x}_{1, \mathrm{t}}=\mathrm{A}_{0} \cdot \Delta \mathbf{x}_{2, \mathrm{t}}+\Gamma_{1,1} \cdot \Delta \mathbf{x}_{1, \mathrm{t}-1}+\cdots+\Gamma_{1 . \mathrm{t}-\mathrm{k}+\mathrm{t}} \cdot \Delta \mathbf{x}_{1, \mathrm{t}-\mathrm{k}+1}+\boldsymbol{\alpha} \cdot \boldsymbol{\beta}^{\prime} \cdot \mathbf{x}_{\mathrm{t}-1}+\boldsymbol{\Phi}_{1} \cdot \mathrm{D}_{\mathrm{t}}+\boldsymbol{\mu}_{0}+\boldsymbol{\varepsilon}_{\mathrm{t}} \\
\quad \text { with }\left\{\mathbf{x}_{\mathrm{t}}\right\}=\left\{\mathbf{x}_{1, \mathrm{t}}, \mathbf{x}_{2, \mathrm{t}}\right\} \quad \text { and }\{\boldsymbol{\alpha}\}=\left\{\boldsymbol{\alpha}_{1}, \boldsymbol{\alpha}_{2}\right\}, \quad \text { whereas } \boldsymbol{\alpha}_{2}=0, \\
\text { with } \boldsymbol{\varepsilon}_{\mathrm{t}} \sim \mathrm{N}_{\mathrm{p}}(0, \Sigma) \quad \text { and }\left\{\mathbf{x}_{\mathrm{t}}\right\}=\left\{\mathbf{x}_{1, \mathrm{t}}, \mathbf{x}_{2, \mathrm{t}}\right\} .
\end{gathered}
$$

Vector $\mathrm{X}_{1}$ includes dispersion, the ppp term, and the risk premium. However, since the extrapolation variable is stationary, it would definitely attract a common stochastic trend in

\footnotetext{
${ }^{18}$ Treating misleadingly nonstationary data as stationary, we would generate spurious regressions without any economic meaning. On the other hand, treating persistent variables as unit-roots makes statistical inference more reliable than otherwise (see Johansen, 1995 and 2006).

${ }^{19}$ Separated for each model, we use the residual series generated by the system estimation and set accordant dummies when standardized errors exceed critical values. Considered dummies need to be statistically significant in the respective model and, additionally, have to be accompanied by a reasonable economic explanation (see Nielsen, 2004).
} 
the system for itself. Additionally, we do not expect the speed in exchange rate changes to be explained in this system, so we treat the difference in the exchange rate as weakly exogenous (i.e. entering $\mathrm{X}_{2}$ ). Furthermore, we include economic reasonable permanent effects via dummy variables in D. Note that these dummies, affecting at least one of the cointegration relations, would be additionally incorporated in $\mathrm{X}_{2}$.

Consulting the specification tests, we construct the specific models for dispersion in the US-dollar, the GB-pound and the JP-yen, respectively. By examining for significant outliers in our data, respective test results notify us that we need to consider two dummy variables in the VEC models. Regarding the GB-pound, two permanent-intervention dummies have to be considered, one in December 1998 and the other in September 2000. Regarding the JP-yen, we need only the permanent-intervention dummy in September 2000. Considering the USdollar, a dummy effect appears in June, 1993, but we do not include it in the model since we cannot find an economic explanation; its consideration does not significantly impact the results.

The December 1998 dummy for the GB-pound seems to be associated with a pronounced change in uncertainty regarding the prospective date of the introduction of the euro in the United Kingdom. In our analyses, this should affect only the GB-pound since the notion of either the US or Japan joining the euro is absurd, and indeed, this effect does not appear in one of the other models. With regard to the September 2000 dummy (regarding GBpound and JP-yen), we connect this reaction to a highly controversial change of the ECB's monetary policy. On September $15^{\text {th }}$, the ECB raised its key interest rate for the first time to vitalize the weak euro. However, financial markets assessed this as insufficient, and sentiment for the euro dropped even further. This argument about ECB's policy raises the question of why we do not find such an effect in the US-dollar equation. Possibly, it is absorbed by the ppp-deviation term, which is most pronounced in US-dollar dispersion among the three models.

Furthermore, whilst US-dollar and GB-pound trace tests show one cointegration relation to be sufficient in the respective systems, the JP-yen, in contrast, requires two long-term relations (see Table 4). Finally, in the course of testing the models for the existence of unitroots, no variable appears to be well approximated by an I(1)-process (see misspecification tests in Appendix 2 and, for further evidence, the multivariate unit-root tests in Appendix 3 ). ${ }^{20}$ Thus, we handle structurally similar models for dispersion in all three exchange rates.

\footnotetext{
${ }^{20}$ By selecting the lag-length of the models, we rely on LR-tests, which show one lag to be sufficient.
} 
Table 5 shows the results of the unrestricted model estimation of US-dollar dispersion. Regarding the long-term relation, dispersion increases significantly when the ppp-deviation becomes smaller and the exchange rate trend or the exchange risk premium rises. As the first two determinants are derived from the $C \& F$ approach, our findings confirm the relevance of the C\&F approach from a new perspective. The source of innovation lies in testing implicit relations regarding expectation heterogeneity in exchange rates. Findings are in accordance with underlying model assumptions and thus confirm the C\&F approach. Moreover, the risk variable, which is unrelated to the $C \& F$ approach variables, has the sign as expected by the noise trading literature. ${ }^{21}$ Turning to dispersion's short-term relation, dispersion error-corrects significantly towards its long-term equilibrium. Moreover, in the short run, the extrapolation variable strongly pushes dispersion. ${ }^{22}$ This impact works in such a manner that the speed of the exchange rate change positively impacts dispersion, indicating the enormous relevance of extrapolation in the short run. An economic interpretation of this short-term effect may be that it indicates heterogeneity within the group of chartists as they react with different speed on the same strong signal (i.e. the exchange rate trend). ${ }^{23}$ The general structure of the model applied to the GB-pound is identical to that applied to the US-dollar, with the exception of two permanent dummies, which enter the error-correction equations as "blips" or one-time effects (see Table 6).

However, the model for the JP-yen differs slightly from the others as can be seen from Table 7. As regards the long-term relations, dispersion in the JP-yen reacts positively when the ppp-deviation decreases or the risk premium increases, which is in line with the two other models. However, the influence of the extrapolation term on expectation heterogeneity turns out to be different. Heterogeneity in the JP-yen error-corrects to a second cointegration relation, in which the risk premium depends positively on the extrapolative term and on the ppp-deviation. Considering both cointegration relations, the effect arising from the pppdeviation term on expectation heterogeneity appears somewhat ambiguous. One may speculate on whether this ambiguity results from Japanese monetary policy. It is known in this regard that the Bank of Japan deliberately influences the JP-yen via extremely low interest rates, as well as exchange rate interventions (see e.g. Frenkel et al., 2004, Ito and Yabu, 2007), which in turn could potentially affect the respective exchange risk premium.

\footnotetext{
${ }^{21}$ However, the influence of risk may also be caused by information heterogeneity (see Bacchetta and van Wincoop, 2006a).

${ }^{22}$ We do not discuss the other error-correction equations as they are not of interest to this research.

${ }^{23} \mathrm{We}$ thank a referee for envisioning this interpretation.
} 
Despite certain particularities of the three models, we emphasize that the baseline structure holds: we find that the $\mathrm{C} \& \mathrm{~F}$ variables and the exchange risk premium show the expected influences on heterogeneity in exchange rate expectations. To check for robustness, we consolidate the unrestricted VEC models to obtain the parsimonious specifications. To conclude, we confirm that dispersion's error-correction remains unchanged regarding all three models as well as extrapolation's positive influence on dispersion in the short run. ${ }^{24}$

\section{Conclusions}

Exchange rate dynamics have not been well understood for the last 30 years. We know that traditional models with representative agents fail seriously when confronted with realworld data. Thus, it is not surprising that simulation results generated by models with heterogeneous agents are more in line with the stylized facts of foreign exchange markets. Many of these models belong to the chartist-fundamentalist approach. Since their empirical analyses rely on simulation studies, our paper contributes by analyzing the determinants of expectation heterogeneity in exchange rates using econometric techniques. Thus, we examine the relevance of the $\mathrm{C} \& \mathrm{~F}$ approach from a different perspective.

We take advantage of our comparatively huge dataset, covering 15 years of exchange rate expectations. By calculating dispersion (i.e. our measure of heterogeneity in exchange rate expectations), we analyze its potential determinants suggested by the exchange rate literature. We find that influences arising from chartists' and fundamentalists' behavior are most useful in explaining heterogeneity, which is in line with the C\&F approach.

Considering the long-term effects, heterogeneity decreases when the exchange rate is farther away from its fundamental equilibrium; according to the $C \& F$ approach this happens because in this case, professionals tend more and more to anticipate exchange rate's meanreversion towards equilibrium. In addition, a stronger change in the exchange rate increases heterogeneity; according to the $\mathrm{C} \& \mathrm{~F}$ approach this is caused by a subsequent shift of opinion, moving from the dominating fundamentalists to the minority group of chartists.

This basic pattern is complemented by a positive influence from the exchange rate risk on heterogeneity. It seems plausible that a risk premium reflects uncertainty; however, this pattern is consistent with competing interpretations. Risk may be caused by noise traders (Jeanne and Rose, 2002) or by uncertainty about the relevant set of information (Bacchetta and van Wincoop, 2006a). Whatever the reason is, this does not contradict the importance of

\footnotetext{
${ }^{24}$ Respective results are available upon request.
} 
the $\mathrm{C} \& \mathrm{~F}$ approach. Its relevance is moreover strengthened by the finding that the fundamentals or the fundamentals' volatility are not important in explaining heterogeneity in exchange rate expectations, at least not in our sample.

\section{References}

Alfarano, S., Lux, T., 2007. A noise trader model as a generator of apparent power laws and long memory. Macroeconomic Dynamics 11, Supplement S1, 80-101.

Alfarano, S., Lux, T., Wagner, F., 2008. Time-variation of higher moments in a financial market with heterogeneous agents: An analytical approach. Journal of Economic Dynamics \& Control 32, 101-136.

Bacchetta, P., van Wincoop, E., 2006a. Can information heterogeneity explain the exchange rate determination puzzle? American Economic Review 96, 552-576.

Bacchetta, P., van Wincoop, E., 2006b. Incomplete information processing: A solution to the forward discount puzzle. CEPR discussion papers.

Bams, D., Walkowiak, K., Wolff, C.C., 2004. More evidence on the dollar risk premium in the foreign exchange market. Journal of International Money and Finance 23, 271-282.

Boswijk, H.P., Hommes, C.H., Manzan, S., 2007. Behavioral heterogeneity in stock prices. Journal of Economic Dynamics and Control 31, 1938-1970.

Brock, W.A., Hommes, C.C., 1998. Heterogeneous beliefs and routes to chaos in a simple asset pricing model. Journal of Economic Dynamics and Control 22, 1235-1274.

Capistrán, C., Timmermann, A., 2006. Disagreement and biases in inflation expectations. Journal of Money, Credit and Banking, forthcoming.

Carlson, J.A., Parkin, M., 1975. Inflation expectations. Economica 42, 123-38.

Chen, S.-H., Lux, T., Marchesi, M., 2001. Testing for non-linear structure in an artificial financial market. Journal of Economic Behavior and Organization 46, 327-342.

Cheung, Y.-W., Chinn, M.D., Garcia Pascual, A., 2005. Empirical exchange rate models of the nineties: Are any fit to survive? Journal of International Money and Finance 24, 1150-1175.

Chiarella, C., Dieci, R., He, X.-Z., 2007. Heterogeneous expectations and speculative behaviour in a dynamic multi-asset framework. Journal of Economic Behavior and Organization 62, 408-427.

Day, R.H., Huang, W., 1990. Bulls, bears and market sheep. Journal of Economic Behavior and Organization 14, 299-329. 
De Grauwe, P., Grimaldi, M., 2006. Exchange rate puzzles: A tale of switching attractors. European Economic Review 50, 1-33.

Elliott, G., Ito, T., 1999. Heterogeneous expectations and tests of efficiency in the Yen/Dollar forward exchange rate market. Journal of Monetary Economics 43, 435-456.

Elliott, G., Komunjer, I., Timmermann, A., 2008. Biases in macroeconomic forecasts: Irrationality or asymmetric loss. Journal of the European Economic Association 6, 122 157.

Flood, R.P., Rose, A.K., 1996. Fixes: Of the forward discount puzzle. Review of Economics and Statistics 128, 748-752.

Frankel, J.A., 1979. On the mark: A theory of floating exchange rate based on real interest differentials. American Economic Review 69, 610-627.

Frankel, J.A., Froot, K.A., 1987. Using survey data to test standard propositions regarding exchange rate expectations. American Economic Review 77, 133-153.

Frankel, J.A., Froot, K.A., 1990a. Chartists, fundamentalists and the demand for dollars. In: Courakis, A.S., Taylor, M.P. (eds.). Private Behaviour and Government Policy in Interdependent Economies. Oxford: Clarendon Press, 73-126.

Frankel, J.A., Froot, K.A., 1990b. Chartists, fundamentalists, and trading in the foreign exchange market. American Economic Review 80, 181-185.

Frankel, J.A., Rose, A.K., 1995. Empirical research on nominal exchange rates. In: Grossmann, G.M., Rogoff, K.S. (Eds.). Handbook of International Economics, Vol. III. Amsterdam: North-Holland, 1689-1729.

Frenkel, M., Pierdzioch, C., Stadtmann, G., 2004. The accuracy of press reports regarding the foreign exchange interventions of the Bank of Japan. Journal of International Financial Markets, Institutions and Money 14, 25-36.

Froot, K.A., Frankel, J.A., 1989. Forward discount bias: Is it an exchange risk premium? Quarterly Journal of Economics 104, 139-161.

Goodman, S.H., 1979. Foreign exchange rate forecasting techniques: Implications for business and policy. Journal of Finance 34, 415-427.

Hau, H., Rey, H., 2006. Exchange rates, stock prices, and capital flows. Review of Financial Studies 9, 273-317.

Ito, T., 1990. Foreign exchange rate expectations: Micro survey data. American Economic Review 80, 434-449. 
Ito, T., Yabu, T., 2007. What prompts Japan to intervene in the Forex market? A new approach to a reaction function. Journal of International Money and Finance 26, 193212.

Jeanne, O., Rose, A.K., 2002. Noise trading and exchange rate regimes. Quarterly Journal of Economics 117, 537-569.

Johansen, S., 1995. Likelihood-based Inference in Cointegrated Vector Auto-regressive Models. Oxford: Oxford University Press.

Johansen, S., 2006. Cointegration: An overview. In: Mills, T.C., Patterson, K. (Eds.). Palgrave Handbook of Econometrics: Volume 1, Econometric Theory. Basingstoke: Palgrave Macmillan, 540-577.

Kilian, L., Taylor, M.P., 2003. Why is it so difficult to beat the random walk forecast of exchange rates? Journal of International Economics 60, 85-107.

Lux, T., 1998. The socio-economic dynamics of speculative markets: interacting agents, chaos, and the fat tails of return distributions. Journal of Economic Behavior and Organization 33, 143-165.

MacDonald, R., 1999. Exchange rates: Do fundamentals matter?. Economic Journal 109, 673691.

MacDonald, R., Marsh, I.W., 1996. Currency forecasters are heterogeneous: Confirmation and consequences. Journal of International Money and Finance 15, 665-685.

Mankiw, N.G., Reis, R., 2002. Sticky information versus sticky prices: A proposal to replace the new Keynesian Phillips curve. Quarterly Journal of Economics 117, 1295-1328.

Mankiw, N.G., Reis, R., Wolfers, J., 2003. Disagreement about inflation expectations. NBER Macroeconomics Annual 2003, 209-48.

Manzan, S., Westerhoff, F., 2005. Representativeness of news and exchange rate dynamics. Journal of Economic Dynamics and Controls 29, 677-689.

Manzan, S., Westerhoff, F., 2007. Heterogeneous expectations, exchange rate dynamics and predictability. Journal of Economic Behavior and Organization 64, 111-128.

Mark, N.C., Wu, Y., 1998. Rethinking deviations from uncovered interest parity: The role of covariance risk and noise. Economic Journal 108, 1686-1706.

Meese, R.A., Rogoff, K., 1983. Empirical exchange rate models of the seventies. Journal of International Economics 14, 3-24.

Menkhoff, L., Taylor, M.P., 2007. The obstinate passion of foreign exchange professionals: Technical analysis. Journal of Economic Literature 45, 936-972. 
Nielsen, H.B., 2004. Cointegration analysis in the presence of outliers. Econometrics Journal 7, 249-271.

Obstfeld, M., Rogoff, K.S., 1995. Exchange rate dynamics redux. Journal of Political Economy 103, 624-660.

Reis, R., 2007. Inattentive consumers. Journal of Monetary Economics 53, 1761-1800.

Sarno, L., Taylor, M.P., 2002. The Economics of Exchange Rates. Cambridge: Cambridge University Press.

Sims, C., 2003. Implications of rational inattention. Journal of Monetary Economics 50, 665690.

Westerhoff, F.H., 2003. Expectations driven distortions in the foreign exchange market. Journal of Economic Behavior and Organization 51, 389-412.

Westerhoff, F.H., Reitz, S., 2003. Nonlinearities and cyclical behavior: The role of chartists and fundamentalists. Studies in Nonlinear Dynamics and Econometrics 7, $1125 \mathrm{ff}$.

Wieland, C., Westerhoff, F.H., 2005. Exchange rate dynamics, central bank interventions and chaos control methods. Journal of Economic Behavior and Organization 58, 117-132.

ZEW Centre for European Economic Research, 2004. Financial Market Report, 13:2. 
TABLE 1 Descriptive statistics of consensus expectations

\begin{tabular}{lcc|cc|cc}
\hline & \multicolumn{2}{c}{ US-dollar } & \multicolumn{2}{c}{ GB-pound } & \multicolumn{2}{c}{ JP-yen } \\
& consensus & dispersion & consensus & dispersion & consensus & dispersion \\
mean & 1.133 & 0.070 & 0.718 & 0.042 & 1.319 & 0.043 \\
std. & 0.120 & 0.017 & 0.065 & 0.011 & 0.136 & 0.009 \\
$25 \%$-q. & 1.049 & 0.058 & 0.671 & 0.035 & 1.231 & 0.036 \\
$75 \%$-q. & 1.225 & 0.078 & 0.762 & 0.047 & 1.402 & 0.048 \\
min. & 0.881 & 0.043 & 0.628 & 0.024 & 0.975 & 0.028 \\
max. & 1.369 & 0.132 & 0.877 & 0.086 & 1.696 & 0.080 \\
\hline
\end{tabular}

Notes: The data series are based upon corresponding 6-months expectations data from Dec. 1991 until Aug. 2006. All series are measured in levels and relate above-mentioned currencies to the D-mark until Dec. 1998 and thereafter to the euro.

TABLE 2 Univariate OLS-regressions of dispersion

$$
\begin{array}{ll}
y_{t}=\alpha+\beta \cdot x_{t}+\varepsilon_{t} & \text { with } \varepsilon_{t} \sim N\left(0, \sigma^{2}\right) \\
y_{t}=\alpha+\beta \cdot\left|x_{t}\right|+\varepsilon_{t} & \text { with } \varepsilon_{t} \sim N\left(0, \sigma^{2}\right) \\
y_{t}=\alpha+\beta_{1} \cdot x_{t}+\beta_{2} \cdot\left|x_{t}\right|+\varepsilon_{t} & \text { with } \varepsilon_{t} \sim N\left(0, \sigma^{2}\right)
\end{array}
$$

\begin{tabular}{lcc|c|c}
\hline & & US-dollar & GB-pound & JP-yen \\
(a) & extrapol. & -0.006 & -0.006 & 0.000 \\
(b) & |extrapol. & 0.100 & 0.067 & 0.092 \\
(c) & {$\left[\right.$ split: $\left.\beta_{1}, \beta_{2}\right]$} & {$\left[0.03,0.37^{* * *}\right]$} & {$\left[0.04,0.25^{* * *}\right]$} & {$\left[0.02,0.15^{* * *}\right]$} \\
& & & \\
(a) & ppp-dev. & 0.018 & 0.165 & 0.522 \\
(b) & |ppp-dev. & 0.029 & 0.295 & 0.550 \\
(c) & {$\left[\right.$ split: $\left.\beta_{1}, \beta_{2}\right]$} & {$\left[0.01^{* *}, 0.03^{*}\right]$} & {$\left[0.01,0.08^{* * *}\right]$} & {$\left[0.02,0.15^{* * *}\right]$} \\
& & & & \\
(a) & risk & 0.113 & 0.299 & 0.476 \\
(b) & $\mid$ risk & 0.436 & 0.468 & 0.512 \\
(c) & {$\left[\right.$ split: $\left.\beta_{1}, \beta_{2}\right]$} & {$\left[-0.08,0.33^{* * *}\right]$} & {$\left[-0.04,0.35^{* * *}\right]$} & {$\left[0.01,0.04^{* * *}\right]$} \\
& & & & \\
(a) & vola. & 0.124 & 0.242 & 0.236 \\
\hline
\end{tabular}

Notes: For data description, see Table 1. The numbers related to equations (a) and (b) document adjusted R-squares of univariate OLS-regressions, in which dispersion is calculated on the displayed variable next to a constant. Here we do not show corresponding probability values, as we focus solely on the explained variances of dispersion. However, the numbers related to equations (c) document the corresponding parameter values. Asterisks refer to the level of significance: ${ }^{*},{ }^{* *},{ }^{* * *}$ to ten, five and one percent. The variables are abbreviated as follows: Current 1-months exchange rate extrapolation (extrapol.), regressive term - i.e. difference between the actual exchange rate and its fair value based upon relative ppp using CPI - (ppp-dev.), risk premia - i.e. the expected (consensus) exchange rate change minus the relative bond rate (risk) and exchange rate volatility - i.e. corresponding 1-month standard-deviation - (vola.). Please note that strokes indicate that the variable appears in absolute measure. 
TABLE 3 Multivariate OLS-regressions of dispersion

\begin{tabular}{|c|c|c|c|}
\hline & US-dollar & GB-pound & JP-yen \\
\hline const. & $0.027^{* * *}$ & 0.026 & $0.015^{* * *}$ \\
\hline $\operatorname{disp}_{(-1)}$ & $0.423^{* * *}$ & $0.655^{* * *}$ & $0.488^{* * *}$ \\
\hline |ppp-dev.| & $-0.033^{* * *}$ & -0.004 & $0.023^{* * *}$ \\
\hline |risk| & $0.229^{* * *}$ & $0.059^{* *}$ & $0.076^{* * *}$ \\
\hline |extrapol.| & $0.249^{* * *}$ & 0.078 & $0.089^{* * *}$ \\
\hline vola. & 0.024 & 0.187 & -0.006 \\
\hline $\operatorname{adj} . \mathrm{R}^{2}$ & 0.641 & 0.746 & 0.755 \\
\hline
\end{tabular}

Notes: For data description, see Table 1. The regressions are calculated by using Newey-West standard errors. The variables are abbreviated as follows: constant (const.), lagged dispersion (disp. ($\left.{ }_{11}\right)$, regressive term - i.e. difference between the actual exchange rate and its fair value based upon relative ppp using CPI - (ppp-dev.), risk premia - i.e. the expected (consensus) exchange rate change minus the relative bond rate (risk), current exchange rate extrapolation (extrapol.) and exchange rate volatility - i.e. corresponding 1-month standard-deviation - (vola.). Please note that strokes indicate that the respective variable appears in absolute measure. Asterisks refer to the level of significance: *, ${ }^{* *},{ }^{* * *}$ to ten, five and one percent.

TABLE 4 Cointegration rank determination (Trace tests)

\begin{tabular}{|c|c|c|c|c|c|}
\hline & & rank three & rank two & rank one & rank zero \\
\hline \multirow[t]{2}{*}{ US-dollar } & $\begin{array}{l}\text { LR-test } \\
\quad \text { [prob. value] }\end{array}$ & $\begin{array}{c}- \\
{[\text { n.a.] }}\end{array}$ & $\begin{array}{l}2.973 \\
{[0.833]}\end{array}$ & $\begin{array}{c}17.010 \\
{[0.385]}\end{array}$ & $\begin{array}{c}52.788^{* * *} \\
{[0.003]}\end{array}$ \\
\hline & $\begin{array}{l}\text { LR-test }^{\#} \\
\quad{\text { [prob. value }]^{\#}}^{\#}\end{array}$ & $\begin{array}{c}- \\
{[\text { n.a.] }}\end{array}$ & $\begin{array}{l}2.879 \\
{[0.844]}\end{array}$ & $\begin{array}{c}16.655 \\
{[0.410]}\end{array}$ & $\begin{array}{c}51.446^{* * *} \\
{[0.005]}\end{array}$ \\
\hline \multirow[t]{2}{*}{ GB-pound } & $\begin{array}{l}\text { LR-test } \\
\quad \text { [prob. value] }\end{array}$ & $\begin{array}{c}- \\
\text { [n.a.] }\end{array}$ & $\begin{array}{l}2.570 \\
{[0.880]}\end{array}$ & $\begin{array}{l}9.378 \\
{[0.916]}\end{array}$ & $\begin{array}{c}60.420^{\text {*** }} \\
{[0.000]}\end{array}$ \\
\hline & $\begin{array}{l}\text { LR-test }^{\#} \\
\quad \text { [prob. value] }^{\#}\end{array}$ & $\begin{array}{c}- \\
\text { [n.a.] }\end{array}$ & $\begin{array}{l}2.416 \\
{[0.896]}\end{array}$ & $\begin{array}{l}9.053 \\
{[0.929]}\end{array}$ & $\begin{array}{c}58.961^{* * *} \\
{[0.001]}\end{array}$ \\
\hline \multirow[t]{2}{*}{ JP-yen } & $\begin{array}{l}\text { LR-test } \\
\quad \text { [prob. value] }\end{array}$ & $\begin{array}{c}- \\
\text { [n.a.] }\end{array}$ & $\begin{array}{l}6.705 \\
{[0.353]}\end{array}$ & $\begin{array}{c}46.968^{* * *} \\
{[0.000]}\end{array}$ & $\begin{array}{c}94.519^{* * *} \\
{[0.000]}\end{array}$ \\
\hline & $\begin{array}{l}\text { LR-test }^{\#} \\
\quad \text { [prob. value] }^{\#}\end{array}$ & $\begin{array}{c}- \\
\text { [n.a.] }\end{array}$ & $\begin{array}{l}6.361 \\
{[0.390]}\end{array}$ & $\begin{array}{c}45.663^{* * *} \\
{[0.000]}\end{array}$ & $\begin{array}{c}94.519^{* * *} \\
{[0.000]}\end{array}$ \\
\hline
\end{tabular}

Notes: The underlying VEC models are estimated using the Maximum Likelihood-method (MLmethod), covering 177 monthly observations, from December 1991 to August 2006. The likelihoodratio-tests and the probability values marked with a hash are the Bartlett-corrected LR-tests and pvalues, necessary to consider sample-size effects on the power of the rank determination. Asterisks refer to the level of significance: ${ }^{*},{ }^{* *},{ }^{* * *}$ to ten, five and one percent. Regarding the US-dollar and the GB-pound, higher-order LR-tests do not reject the null hypothesis of one unit-root. Different from the others, the JP-yen reveals two long-term relations. 
TABLE 5 The unrestricted VEC model for the US-dollar

$$
\begin{aligned}
\Delta \mathbf{x}_{1, \mathrm{t}} & =\boldsymbol{\theta}^{\prime} \cdot \Delta \mathrm{x}_{2, \mathrm{t}}+\Gamma_{1.1} \cdot \Delta \mathbf{x}_{1, \mathrm{t}-1}+\boldsymbol{\alpha} \cdot \boldsymbol{\beta}^{\prime} \cdot \mathrm{x}_{\mathrm{t}-1}+\boldsymbol{\varepsilon}_{t} \\
& \text { with }\left\{\mathbf{x}_{\mathrm{t}}\right\}=\left\{\mathbf{x}_{1, \mathrm{t}}, \mathrm{x}_{2, \mathrm{t}}\right\} \quad \text { and }\{\boldsymbol{\alpha}\}=\left\{\boldsymbol{\alpha}_{1}, 0\right\} \quad \text { with } \boldsymbol{\varepsilon}_{\mathrm{t}} \sim \mathrm{N}_{\mathrm{p}}(0, \Sigma)
\end{aligned}
$$

cointegration equation:

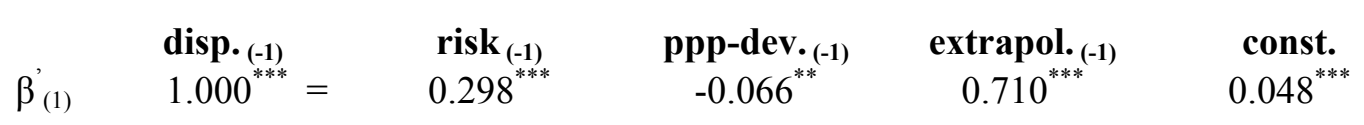

\begin{tabular}{|c|c|c|c|}
\hline $\begin{array}{l}\alpha_{(1)} \\
\text { [t-value] }\end{array}$ & $\begin{array}{c}\Delta \text { disp. } \\
-0.421^{* * *} \\
{[-5.310]}\end{array}$ & $\begin{array}{c}\Delta \text { risk } \\
-0.114 \\
{[-1.096]}\end{array}$ & $\begin{array}{c}\Delta \text { ppp-dev. } \\
-0.309^{* *} \\
{[-2.041]}\end{array}$ \\
\hline $\begin{array}{l}\Delta \text { disp. }_{(-1)} \\
\text { [t-value] }\end{array}$ & $\begin{array}{l}-0.123 \\
{[-1.318]}\end{array}$ & $\begin{array}{r}-0.021 \\
{[-0.175]}\end{array}$ & $\begin{array}{l}0.190 \\
{[1.061]}\end{array}$ \\
\hline $\begin{array}{l}\Delta \text { risk }_{(-1)} \\
\text { [t-value] }\end{array}$ & $\begin{array}{l}0.030 \\
{[0.388]}\end{array}$ & $\begin{array}{l}0.002 \\
{[0.022]}\end{array}$ & $\begin{array}{c}-0.411^{* * *} \\
{[-2.828]}\end{array}$ \\
\hline $\begin{array}{l}\Delta \text { ppp-dev } \\
\text { [t-value] }\end{array}$ & $\begin{array}{l}0.053 \\
{[1.372]}\end{array}$ & $\begin{array}{l}0.041 \\
{[0.818]}\end{array}$ & $\begin{array}{c}0.264^{* * *} \\
{[3.582]}\end{array}$ \\
\hline $\begin{array}{l}\Delta \text { extrapol. }_{(0)} \\
\text { [t-value] }\end{array}$ & $\begin{array}{c}0.309^{* * *} \\
{[6.718]}\end{array}$ & $\begin{array}{c}0.130^{* *} \\
{[2.163]}\end{array}$ & $\begin{array}{l}0.015 \\
{[0.166]}\end{array}$ \\
\hline $\begin{array}{l}\Delta \text { extrapol}_{(-1)} \\
\text { [t-value] }\end{array}$ & $\begin{array}{c}-0.018 \\
{[-0.341]}\end{array}$ & $\begin{array}{l}-0.078 \\
{[-1.129]}\end{array}$ & $\begin{array}{l}-0.060 \\
{[-0.589]}\end{array}$ \\
\hline $\begin{array}{l}\text { adj. } R^{2} \\
\text { sum resid }\end{array}$ & $\begin{array}{l}0.289 \\
0.021\end{array}$ & $\begin{array}{l}0.030 \\
0.037\end{array}$ & $\begin{array}{l}0.131 \\
0.078\end{array}$ \\
\hline
\end{tabular}

error-correction equations:

Notes: The VEC model is estimated using the ML-method. The sample contains 177 monthly observations, from December 1991 to August 2006. The variables are calculated in absolute values and are abbreviated as follows: Dispersion (disp.), risk premium (risk), regressive term (ppp-dev.) - i.e. current exchange rate minus fair value upon the relative ppp concept using CPI data - as well as 1month exchange rate extrapolation (extrapol.). Based upon calculated $t$-values, corresponding cointegration parameters are highly significant. Nevertheless, since the test-statistics are not valid, they are limited to providing rough indications about the significances, which is why we do not represent them. Therefore, we conduct accordant Wald-tests so that the asterisks relate to the Bartlett-corrected test statistics, which we assume follow a $\chi 2$-distribution with degree of one. The log-likelihood of the system yields 2264.205. Asterisks refer to the regressors' level of significance in the short-term relations: ${ }^{*},{ }^{* *},{ }^{* * *}$ to ten, five and one percent. 
TABLE 6 The unrestricted VEC model for the GB-pound

$$
\begin{aligned}
\Delta \mathbf{x}_{1, \mathrm{t}} & =\boldsymbol{\theta}^{\prime} \cdot \Delta \mathrm{x}_{2, \mathrm{t}}+\Gamma_{1.1} \cdot \Delta \mathbf{x}_{1, \mathrm{t}-1}+\boldsymbol{\alpha} \cdot \boldsymbol{\beta}^{\prime} \cdot \mathrm{x}_{\mathrm{t}-1}+\Phi_{1} \cdot D_{t}+\boldsymbol{\varepsilon}_{t} \\
& \text { with }\left\{\mathbf{x}_{\mathrm{t}}\right\}=\left\{\mathbf{x}_{1, \mathrm{t}}, \mathrm{x}_{2, \mathrm{t}}\right\} \quad \text { and }\{\boldsymbol{\alpha}\}=\left\{\boldsymbol{\alpha}_{1}, 0\right\} \quad \text { with } \boldsymbol{\varepsilon}_{\mathrm{t}} \sim \mathrm{N}_{\mathrm{p}}(0, \Sigma)
\end{aligned}
$$

cointegration equation:

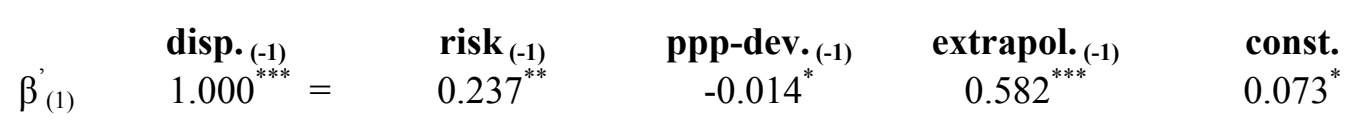

\begin{tabular}{|c|c|c|c|}
\hline $\begin{array}{l}\alpha_{(1)} \\
\text { [t-value] }\end{array}$ & $\begin{array}{c}\Delta \text { disp. } \\
-0.275^{* * *} \\
{[-5.629]}\end{array}$ & $\begin{array}{c}\Delta \text { risk } \\
0.132^{* *} \\
{[2.265]}\end{array}$ & $\begin{array}{c}\Delta \text { ppp-dev. } \\
-0.349^{*} \\
{[-1.747]}\end{array}$ \\
\hline $\begin{array}{l}\Delta \text { disp. }_{(-1)} \\
\text { [t-value] }\end{array}$ & $\begin{array}{r}-0.017 \\
{[-0.261]}\end{array}$ & $\begin{array}{c}0.195^{* *} \\
{[2.521]}\end{array}$ & $\begin{array}{c}0.674^{* *} \\
{[2.539]}\end{array}$ \\
\hline $\begin{array}{l}\Delta \text { risk }_{(-1)} \\
\text { [t-value] }\end{array}$ & $\begin{array}{l}0.011 \\
{[0.186]}\end{array}$ & $\begin{array}{c}-0.134^{*} \\
{[-1.819]}\end{array}$ & $\begin{array}{c}-0.197 \\
{[-0.780]}\end{array}$ \\
\hline $\begin{array}{l}\Delta \text { ppp-dev.(-1) } \\
{[\text { [t-value] }}\end{array}$ & $\begin{array}{c}-0.036^{* *} \\
{[-1.998]}\end{array}$ & $\begin{array}{c}0.043^{* *} \\
{[2.029]}\end{array}$ & $\begin{array}{c}0.170^{* *} \\
{[2.329]}\end{array}$ \\
\hline $\begin{array}{l}\Delta \text { extrapol }_{(0)} \\
\text { [t-value] }\end{array}$ & $\begin{array}{c}0.155^{* * *} \\
{[6.011]}\end{array}$ & $\begin{array}{l}0.033 \\
{[1.068]}\end{array}$ & $\begin{array}{c}0.440^{* * *} \\
{[4.174]}\end{array}$ \\
\hline $\begin{array}{l}\Delta \text { extrapol}_{(-1)} \\
{[\text { t-value] }}\end{array}$ & $\begin{array}{l}-0.006 \\
{[-0.206]}\end{array}$ & $\begin{array}{l}0.027 \\
{[0.817]}\end{array}$ & $\begin{array}{l}0.193^{*} \\
{[1.709]}\end{array}$ \\
\hline $\begin{array}{l}\Delta \text { du00099 } \\
\text { [t-value] }\end{array}$ & $\begin{array}{c}0.017^{* * *} \\
{[3.829]}\end{array}$ & $\begin{array}{l}-0.001 \\
{[-0.181]}\end{array}$ & $\begin{array}{l}0.004 \\
{[0.224]}\end{array}$ \\
\hline $\begin{array}{l}\Delta \text { du9812 } \\
\text { [t-value] }\end{array}$ & $\begin{array}{c}0.036^{* * *} \\
{[7.828]}\end{array}$ & $\begin{array}{l}-0.003 \\
{[-0.573]}\end{array}$ & $\begin{array}{l}0.020 \\
{[1.089]}\end{array}$ \\
\hline $\begin{array}{l}\text { adj. } \mathrm{R}^{2} \\
\text { sum resid }\end{array}$ & $\begin{array}{l}0.408 \\
0.003\end{array}$ & $\begin{array}{l}0.093 \\
0.005\end{array}$ & $\begin{array}{l}0.111 \\
0.058\end{array}$ \\
\hline
\end{tabular}

error-correction equations:

Notes: See Table 5. Moreover, specification tests showed the necessity of implementing a mean-shift dummy in September 2000 (du0009) and a permanent-intervention dummy in December 1998. Based upon calculated t-values, corresponding cointegration parameters are highly significant. In addition (see Table 5), we conduct accordant Wald-tests so that the asterisks relate to the Bartlett-corrected test statistics, which we assume follow a $\chi 2$-distribution with degree of one. The log-likelihood of the system yields 2579.982. Asterisks refer to the regressors' level of significance in the short-term relations: ${ }^{* * *},{ }^{* * *}$ to ten, five and one percent. 
TABLE 7 The unrestricted VEC model for the JP-yen

$$
\begin{aligned}
\Delta \mathbf{x}_{1, \mathrm{t}} & =\boldsymbol{\theta}^{\prime} \cdot \Delta \mathrm{x}_{2, \mathrm{t}}+\Gamma_{1.1} \cdot \Delta \mathbf{x}_{1, \mathrm{t}-1}+\boldsymbol{\alpha} \cdot \boldsymbol{\beta}^{\prime} \cdot \mathrm{x}_{\mathrm{t}-1}+\Phi_{1} \cdot D_{t}+\boldsymbol{\varepsilon}_{t} \\
& \text { with }\left\{\mathbf{x}_{\mathrm{t}}\right\}=\left\{\mathbf{x}_{1, \mathrm{t}}, \mathrm{x}_{2, \mathrm{t}}\right\} \quad \text { and }\{\boldsymbol{\alpha}\}=\left\{\boldsymbol{\alpha}_{1}, 0\right\} \quad \text { with } \boldsymbol{\varepsilon}_{\mathrm{t}} \sim \mathrm{N}_{\mathrm{p}}(0, \Sigma)
\end{aligned}
$$

\begin{tabular}{|c|c|c|c|c|c|}
\hline & $\operatorname{disp}_{(-1)}$ & $\operatorname{risk}_{(-1)}$ & ppp-dev. (-1) & extrapol$_{\cdot(-1)}$ & const. \\
\hline (1) & $1.000^{* * *}=$ & $0.400^{* * *}$ & $-0.032^{* * *}$ & n.a & $0.033^{* * *}$ \\
\hline$\beta_{(2)}^{\prime}$ & n.a. & $1.000^{* * *}=$ & $0.224^{* * *}$ & $0.660^{* * *}$ & $-0.012^{*}$ \\
\hline
\end{tabular}

cointegration equation:

\begin{tabular}{|c|c|c|c|}
\hline $\begin{array}{l}\alpha_{(1)} \\
\text { [t-value] }\end{array}$ & $\begin{array}{c}\Delta \text { disp. } \\
-0.450^{* * *} \\
{[-6.422]}\end{array}$ & $\begin{array}{c}\Delta \text { risk } \\
-0.234^{* *} \\
{[-2.566]}\end{array}$ & $\begin{array}{c}\Delta \text { ppp-dev. } \\
0.640 \\
{[1.476]}\end{array}$ \\
\hline $\begin{array}{l}\alpha_{(2)} \\
{[t-v a l u e]}\end{array}$ & $\begin{array}{c}-0.136^{* * *} \\
{[-5.315]}\end{array}$ & $\begin{array}{c}-0.217^{* * *} \\
{[-6.534]}\end{array}$ & $\begin{array}{l}0.091 \\
{[0.576]}\end{array}$ \\
\hline $\begin{array}{l}\Delta \text { disp. }_{(-1)} \\
\text { [t-value] }\end{array}$ & $\begin{array}{l}0.020 \\
{[0.272]}\end{array}$ & $\begin{array}{c}0.221^{* *} \\
{[2.288]}\end{array}$ & $\begin{array}{l}-0.397 \\
{[-0.864]}\end{array}$ \\
\hline $\begin{array}{l}\Delta \text { risk }_{(-1)} \\
\text { [t-value] }\end{array}$ & $\begin{array}{l}0.047 \\
{[0.857]}\end{array}$ & $\begin{array}{l}-0.107 \\
{[-1.479]}\end{array}$ & $\begin{array}{c}-0.942^{* * *} \\
{[-2.751]}\end{array}$ \\
\hline $\begin{array}{l}\Delta \text { ppp-dev }_{\cdot(-1)} \\
{[\text { t-value] }}\end{array}$ & $\begin{array}{l}-0.001 \\
{[-0.082]}\end{array}$ & $\begin{array}{l}-0.006 \\
{[-0.329]}\end{array}$ & $\begin{array}{l}0.037 \\
{[0.449]}\end{array}$ \\
\hline $\begin{array}{l}\Delta \text { extrapol}_{(0)} \\
\text { [t-value] }\end{array}$ & $\begin{array}{c}0.081^{* * *} \\
{[5.103]}\end{array}$ & $\begin{array}{c}0.084^{* * *} \\
{[4.048]}\end{array}$ & $\begin{array}{l}-0.060 \\
-[0.613]\end{array}$ \\
\hline $\begin{array}{l}\Delta \text { extrapol}_{(-1)} \\
\text { [t-value] }\end{array}$ & $\begin{array}{l}-0.011 \\
{[-0.630]}\end{array}$ & $\begin{array}{c}-0.046^{* *} \\
{[-2.104]}\end{array}$ & $\begin{array}{l}-0.024 \\
{[-0.230]}\end{array}$ \\
\hline $\begin{array}{l}\Delta \text { du } 0009_{(0)} \\
\text { [t-value] }\end{array}$ & $\begin{array}{c}0.023^{* * *} \\
{[5.060]}\end{array}$ & $\begin{array}{l}0.000 \\
{[0.028]}\end{array}$ & $\begin{array}{c}0.065^{* *} \\
{[2.377]}\end{array}$ \\
\hline $\begin{array}{l}\text { adj. } R^{2} \\
\text { sum resid }\end{array}$ & $\begin{array}{l}0.364 \\
0.003\end{array}$ & $\begin{array}{l}0.265 \\
0.006\end{array}$ & $\begin{array}{l}0.070 \\
0.123\end{array}$ \\
\hline
\end{tabular}

error-correction equations:

Notes: See Table 5. Moreover, specification tests showed the necessity of implementing a permanentintervention dummy in September 2000 (du0009). In addition (see Table 5), we conduct accordant Wald-tests so that the asterisks relate to the Bartlett-corrected test statistics, which we assume follow a $\chi 2$-distribution with degree of three. The log-likelihood of the system yields 2468.597 . Asterisks refer to regressors' level of significance in the short-term relations: ${ }^{*},{ }^{* *},{ }^{* * *}$ to ten, five and one percent. 
FIGURE 1 Histograms of dispersion in US-dollar, GB-pound and JP-yen
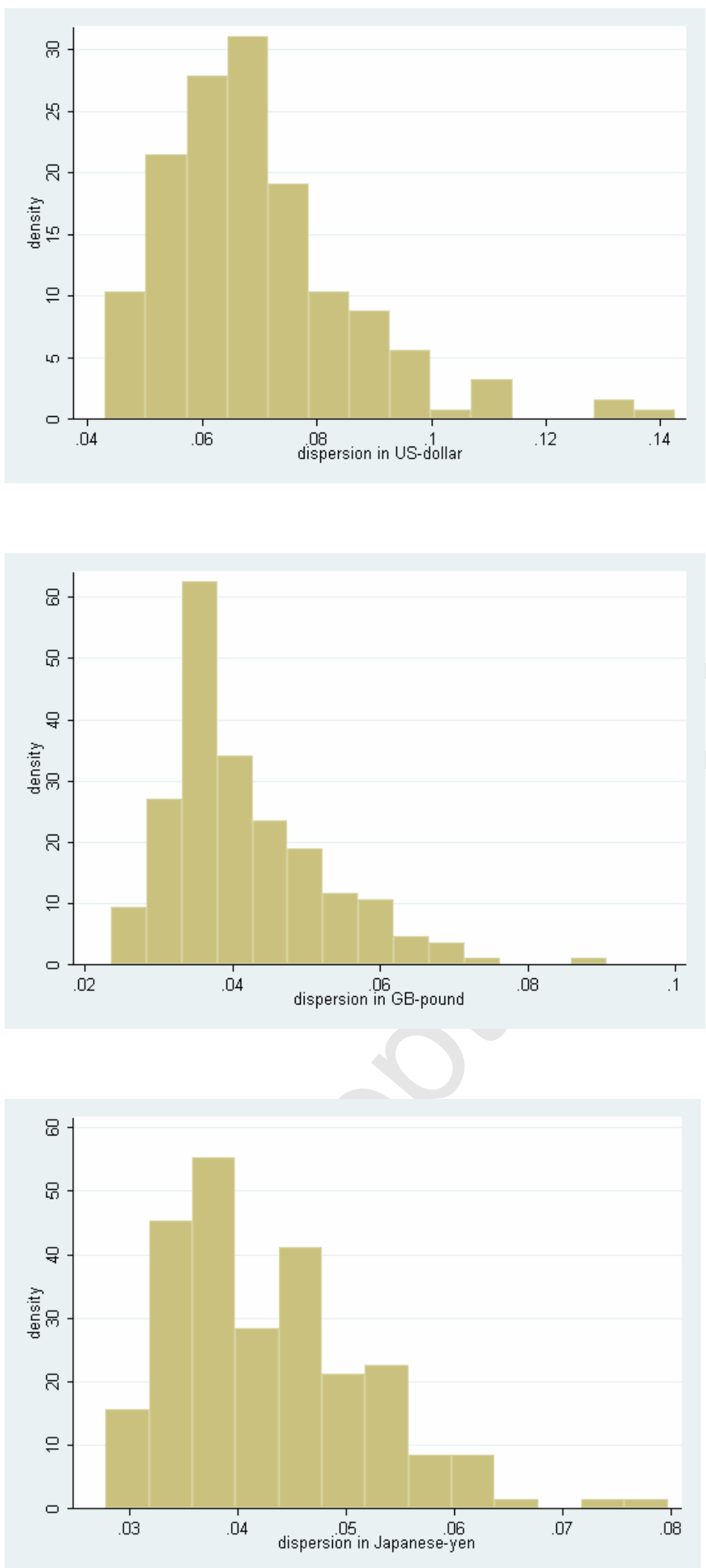

Notes: The dispersion series are based upon 6-month expectations data from Dec. 1991 until Aug. 2006. These histograms show the distribution of dispersion, when moving from top to bottom, in the euro/US-dollar, euro/GB-pound and euro/JP-yen (each with the D-Mark/- respectively). 
FigURE 2 Dispersion in US-dollar, GB-pound and JP-yen

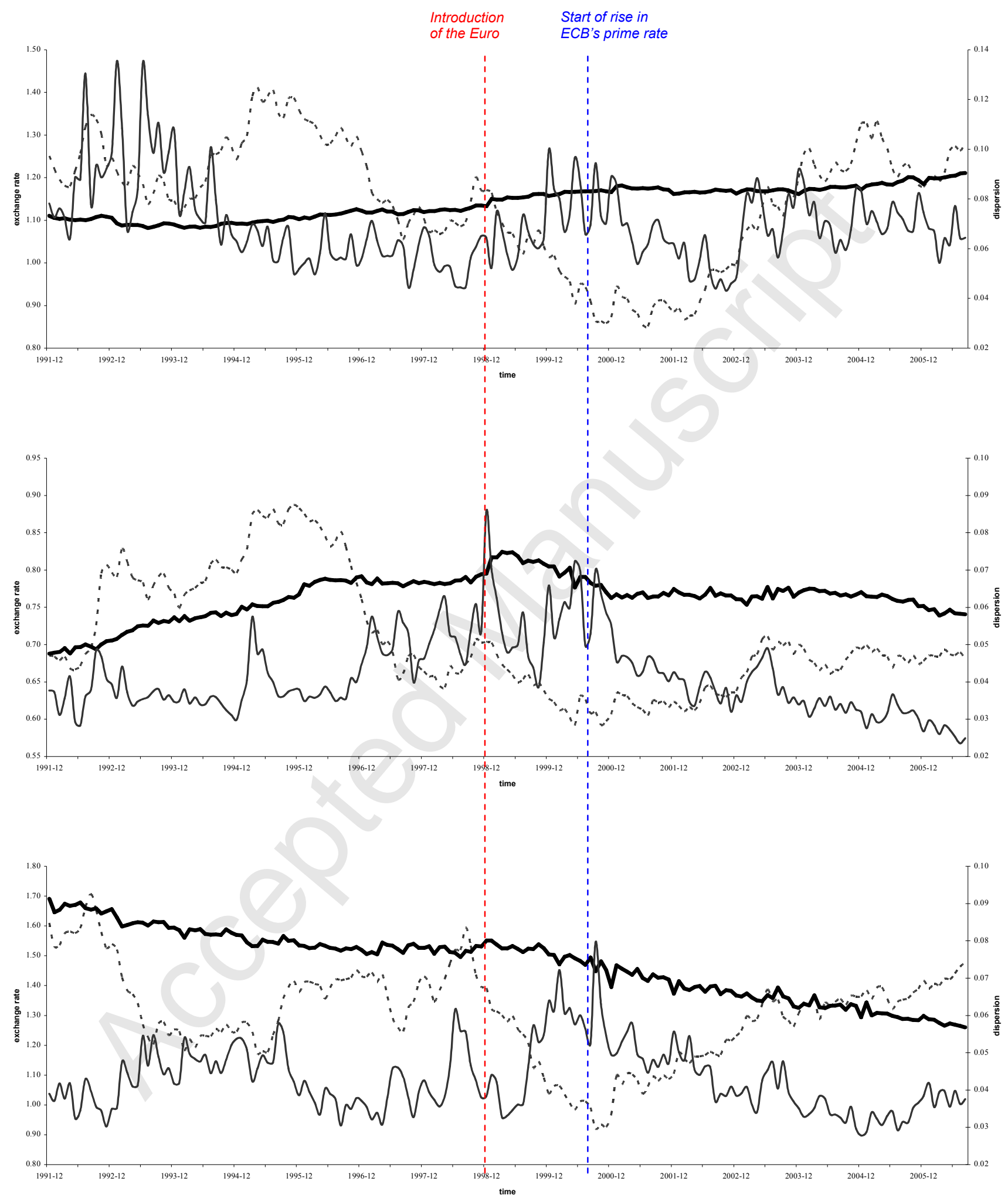

Notes: The dispersion series are based upon 6-month expectations data from Dec. 1991 until Aug. 2006. The graphs show the time series of dispersion, the related spot rate as well as the ppp-rate separately (moving from top to bottom) in the euro/US-dollar, euro/GB-pound and euro/JP-yen (each with the D-Mark/- respectively). Dashed horizontal lines represent the spot rates, whereas fine solid lines show the corresponding dispersion series and bold solid lines the corresponding ppp rates. Moreover, two dashed vertical lines represent the dummy events. 


\section{Appendix}

APPENDIX 1 Consulted set of explanatory variables on dispersion

in signed values in absolute values

volatility

\begin{tabular}{ccc}
$\Delta$ money M2 $^{*}$ & $\mathrm{x}$ & $\mathrm{x}$ \\
$\Delta$ money M3 $^{*}$ & $\mathrm{x}$ & $\mathrm{x}$ \\
industrial production $^{*}$ & $\mathrm{x}$ & $\mathrm{x}$ \\
$\Delta \mathrm{GDP}^{*}$ & $\mathrm{x}$ & $\mathrm{x}$ \\
CPI inflation $^{*}$ & $\mathrm{x}$ & $\mathrm{x}$ \\
relative trade balance $^{*}$ & $\mathrm{x}$ & $\mathrm{x}$ \\
6-month LIBOR rate $^{*}$ & $\mathrm{x}$ & $\mathrm{x}$ \\
10-year bond yields $^{*}$ & $\mathrm{x}$ & $\mathrm{x}$ \\
$\Delta$ stock index $^{*}$ & $\mathrm{x}$ & $\mathrm{x}$ \\
1-month $\Delta$ exchange rate $_{\text {6-month } \Delta \text { exchange rate }}$ & $\mathrm{x}$ & $\mathrm{x}$ \\
ppp-deviation $(\mathrm{CPI})$ & $\mathrm{x}$ & $\mathrm{x}$ \\
risk premium & - & $\mathrm{x}$ \\
exchange rate volatility & - & $\mathrm{x}$ \\
\hline
\end{tabular}

$\begin{array}{ll}x & x \\ x & x \\ x & x \\ x & x \\ x & x \\ x & x \\ x & x \\ x & x \\ x & x \\ x & - \\ x & - \\ x & - \\ x & - \\ - & x\end{array}$

Notes: Our sample contains monthly data from December 1991 until August 2006, which amounts to 177 observations, with the exception of the financial series, for which we use daily data in order to consider the dates of the individual expectations. All variables marked with an asterisk are generated by the difference between the euro zone and the United States, Great Britain and Japan (Germany until December 1998, respectively). Data in money (M2, M3), industrial production, GDP, CPI as well as trade balance stem from the IMF's International Financial Statistics. Furthermore, 6-month Libor rates, stock indices are taken from EcoWin. Daily data on German government bond yields are picked up from the Deutsche Bundesbank, US yields from the Federal Reserve GB yields, British yields from the Bank of England and accordant Japanese yields from the Bank of Japan. Daily exchange rate data of the US-dollar/euro, GB-pound/euro and JP-yen/euro (until December 1998 -/D-mark, respectively) stem again from the Deutsche Bundesbank. 
APPENDIX 2 Misspecification tests for VEC models

\begin{tabular}{|c|c|c|c|c|c|c|}
\hline \multicolumn{7}{|c|}{ tests for autocorrelation } \\
\hline & \multicolumn{2}{|c|}{ US-dollar } & \multicolumn{2}{|c|}{ GB-pound } & \multicolumn{2}{|c|}{ JP-yen } \\
\hline & $X^{2}$ & [prob. value] & $X^{2}$ & [prob. value] & $X^{2}$ & [prob. value] \\
\hline LM-test $^{(1)}$ : & 10.700 & [0.297] & 9.888 & {$[0.360]$} & 13.894 & {$[0.126]$} \\
\hline LM-test $^{(2)}:$ & $20.692^{* *}$ & {$[0.014]$} & 1691 & {$[0.995]$} & 14.198 & {$[0.115]$} \\
\hline LM-test $^{(3)}$ : & 9.382 & {$[0.403]$} & 15.768 & {$[0.072]$} & 7.541 & {$[0.581]$} \\
\hline LM-test $^{(4)}$ : & $14.755^{*}$ & {$[0.098]$} & 5.546 & {$[0.784]$} & 11.237 & {$[0.260]$} \\
\hline LM-test $^{(5)}$ : & 9.001 & {$[0.437]$} & 16.030 & {$[0.066]$} & 7.343 & {$[0.602]$} \\
\hline \multicolumn{7}{|c|}{ test for normality } \\
\hline LM-test $^{(.)}$: & $25.591^{* * *}$ & {$[0.000]$} & $10.060^{* *}$ & {$[0.122]$} & 22.99 & {$[0.001]$} \\
\hline \multicolumn{7}{|c|}{ tests for ARCH } \\
\hline LM-test $^{(1)}$ : & $48.789^{*}$ & {$[0.076]$} & 72.171 & {$[0.000]$} & 32.578 & {$[0.632]$} \\
\hline LM-test $^{(2)}$ : & 70.963 & {$[0.512]$} & $95.233^{* * *}$ & {$[0.035]$} & $99.153^{* *}$ & {$[0.019]$} \\
\hline
\end{tabular}

Notes: See Tables 5-7 for data and the VEC estimations. The multivariate maximum-likelihood-test of order two shows some autocorrelation for the US-dollar (but up to order ten, no further autocorrelation exists). However, it seems noteworthy that this traces back to residual correlation between dispersion's and risk premium's short-term relation (i.e. amounting to 0.662). Based on the parsimonious version of the model and correcting for related simultaneous effects, autocorrelation dies out. The test for normality reveals that the residuals do not closely follow a normal distribution. Accordant univariate tests reveal that this is due to skewness and kurtosis in dispersion and the risk premium. Moreover, tests for ARCH-effects do not indicate heteroskedasticity in the data. However, results based upon the Gaussian-likelihood are asymptotically robust to some types of deviations of the residuals from the Gaussian distribution, for example, heteroskedasticity and non-normality (see Johansen, 2006). Asterisks refer to the level of significance: ${ }^{* * *},{ }^{* * *}$ to ten, five and one percent.

APPENDIX 3 Multivariate LR-tests of unit-roots

\begin{tabular}{ccccc}
\multirow{4}{*}{ US-dollar } & & disp. & risk & ppp-dev. \\
& rank one & $10.526^{* * *}$ & $26.946^{* * *}$ & $27.326^{* * *}$ \\
& [prob. value] & {$[0.005]$} & {$[0.000]$} & {$[0.000]$} \\
\cline { 2 - 5 } GB-pound & & & $38.982^{* * *}$ & $47.393^{* * *}$ \\
& & & {$[0.000]$} & {$[0.000]$} \\
& rank one & $11.917^{* * *}$ & & \\
\cline { 2 - 5 } JP-yen & [prob. value] & {$[0.003]$} & $32.063^{* * *}$ & $34.042^{* * *}$ \\
& & & {$[0.000]$} & {$[0.000]$} \\
& rank one & $25.393^{* * *}$ & $29.334^{* * *}$ & $27.833^{* * *}$ \\
& [prob. value] & {$[0.000]$} & {$[0.000]$} & {$[0.000]$} \\
\hline & rank two & $19.7890^{* * *}$ & {$[0.000]$} &
\end{tabular}

Notes: See Tables 5-7 for the data, variables and the underlying VEC-models. Included constants are restricted to the cointegration space. The numbers in brackets are corresponding probability values of the tests. Since the Trace tests in Table 4 reveal the ranks separated for each exchange rate, we concentrate on respective likelihood-ratio-tests. The above results show clearly that the uncovered longterm relations do not constitute a unit-root underlying one of the endogenous variables. Asterisks refer to the level of significance: ${ }^{*},{ }^{* *},{ }^{* * *}$ to ten, five and one percent. 